\title{
Correction to: Vendor boundary spanning in Indian Information Technology (IT) companies
}

\section{Smita Prashant Chattopadhyay ${ }^{1}$ (D) $\cdot$ Madhuchhanda Das Aundhe ${ }^{2}$ (D)}

Published online: 27 January 2020

(C) Springer Science+Business Media, LLC, part of Springer Nature 2020

\section{Correction to: Asia Pacific Journal of Management https://doi.org/10.1007/s10490-019-09696-8}

The original version of this article unfortunately contained mistakes. Figure 3(a) and 3(b) in Appendix $\mathrm{C}$ were misplaced and not appropriately mentioned. Figure 3(a) needs to be listed under Appendix C (b) and Figure 3(b) needs to be listed under Appendix C (c).

The original article has been corrected.

Smita Prashant Chattopadhyay

smita@iimtrichy.ac.in

Madhuchhanda Das Aundhe

madhu.das@gmail.com

1 Indian Institute of Management Tiruchirappalli, Pudukottai Main Road, Chinna Sooriyur Village, Tiruchirappalli, Tamil Nadu 620024, India

2 Independent Researcher, 1A, Classic Residency, 8/1, 15th Cross, Eswara Layout, Indiranagar 2nd Stage, Bangalore, Karnataka 560038, India 